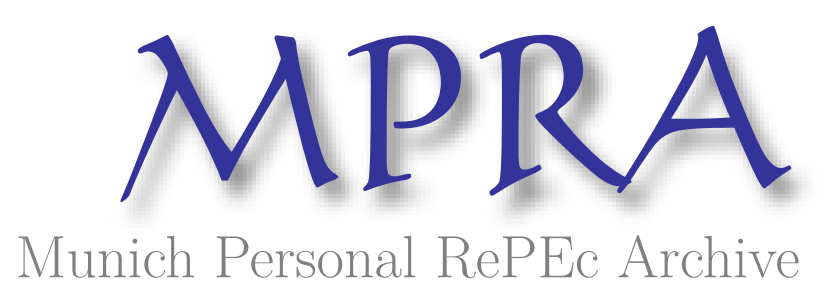

\title{
Is MA different during a crisis? Evidence from the European banking sector
}

Beltratti, Andrea and Paladino, Giovanna

Bocconi University Milano Italy, Intesa Sanpaolo

25 November 2011

Online at https://mpra.ub.uni-muenchen.de/35065/

MPRA Paper No. 35065, posted 28 Nov 2011 19:45 UTC 
Is M\&A different during a crisis? Evidence from the European banking sector

by

Andrea Beltratti and Giovanna Paladino*

November 2011

Keywords: Mergers and Acquisitions, Banks. Opacity, Financial crisis JEL G21. G34

\footnotetext{
*Andrea Beltratti

Bocconi University, Italy

e-mail: andrea.beltratti@unibocconi.it

Giovanna Paladino

IntesaSanpaolo, Italy

e-mail: giovanna.paladino@intesasanpaolo.com
} 


\begin{abstract}
The financial crisis has affected the landscape of the banking sector around the world. We use a sample of transactions taking place in Europe in 2007-2010 to study the acquirer's stock price market reaction to announcements and completions of acquisitions. We find that there are no significant abnormal returns around the announcement of an acquisition while there are positive abnormal returns at completions. We study the cross-sectional determinants of abnormal returns and find that announcement returns are mainly explained by the acquirer bank characteristics, while completion returns depend on opacity of the target and in large part on the drop in volatility associated with a reduction of uncertainty.
\end{abstract}




\section{Introduction.}

Acquisitions in the banking sector may be driven by a multiplicity of factors among which are: (i) exploiting economies of scale associated with centralizing functions like IT, cash management, personnel, (ii) exerting market power and imposing better pricing conditions on customers, (iii) pursuing geographical diversification that brings benefits in terms of risk reduction, (iv) taking advantage from implicit subsidies connected with a too-big-to-fail (TBTF) ${ }^{1}$ status, (v) managers maximizing their own utility function rather than the shareholders utility function.

Empirical studies of mergers and acquisitions (M\&A) usually show that abnormal returns around the announcement date are negative for acquirers and positive for targets, see e.g. Spyrou and Siougle (2010), Campa and Hernando (2006), Karceski, Ongena and Smith (2005). However, recent evidence is not totally consistent with these results. Moeller and Faelton (2009) ${ }^{2}$ show that, since 2008, acquirers have significantly positive abnormal returns around the date of either announcement or completion. In their review of the post-2000 literature, DeYoung et al. (2009) come to the conclusion that "North American bank mergers are (or can be) efficiency improving. European bank mergers appear to have resulted in both efficiency gains and stockholder value enhancement". Moreover, Netter, Stegemoller and Wintoki (2011) show that some of the results found in the literature may be sample specific and may not hold for a wider sample with a higher representation of private bidders and small targets.

In this paper we contribute to the literature by studying the cross-sectional determinants of stock returns to acquirers in the banking sector during the recent credit crisis. We focus on acquisitions in the banking sector in the European Union that have been completed or terminated over the period 2007-2010. This sample period is particularly interesting because transactions may have involved banks that were sufficiently strong to take advantage - at a time of liquidity shortage - of forced sales from weaker competitors. We make two conjectures: first, in a buyer's market, positive

\footnotetext{
${ }^{1}$ Demirguc-Kunt and Huizinga (2010) find that some banks may have grown to a size that prevents them from gaining benefits from the TBTF characteristic.

${ }^{2}$ See also Towers Watson and Cass Business School, 2011, Quarterly Deal Performance Q1 2001, April.
} 
abnormal returns should be easier to detect than in normal periods, and, second, opacity of banks balance sheets may have been particularly relevant at this time so that the combination of greater overall uncertainty and asset opacity may have caused investors to be more cautious in reacting to the announcement and attaching some value to completion of the process.

To elaborate on these hypotheses we notice that crises may represent opportunities for strong banks. Healthy banks, particularly from the point of view of capital and liquidity, have an opportunity to improve their market share and profitability during crises, see Berger and Bouwman (2008), and may shop around and buy competitors at distressed prices. Acharya, Shin and Yorulmazer (2011) claim that the gains from acquiring assets at fire-sale prices during a crisis is one of the reasons explaining bank holdings of liquid assets in normal times. Acquisitions at times of crises may therefore imply positive abnormal returns as acquirers would be able to achieve portfolio diversification (Emmons et al. 2004), geographic diversification (Hughes et al. 1999), activity diversification (Van Lelyveld and Knot 2009) and market power (Hankir et al. 2011) at low prices. A reduction in the number of potential bidders and an increase in the number of potential targets, typical of crisis periods, may also allow stock prices to more clearly reflect advantages for the acquirers see James and Wier (1987). At the aggregate level, a negative effect on abnormal returns can be associated with acquisitions that are forced by regulators. It is recognized, see e.g. Koetter et al (2007), that M\&A in banking may also be due interventions on the part of regulators and generally involves financially weak target banks. Acquisitions in the banking sector during the crisis may have been motivated by an attempt on the part of the public sector to prevent bank failures and to limit the extent of public interventions (see e.g. Group of Thirty, 2009). This would be coherent with finding negative abnormal returns, perhaps due to increases in risk $^{3}$, for acquirers that may have been forced to intervene due to external pressure from regulators.

\footnotetext{
${ }^{3}$ Vallascas and Hegendorff (2011) study a sample of 134 acquisitions in Europe and find that mergers on average do not affect risk as measured by the distance to default, but that relatively safe banks suffer from an increase in risk following the announcement of the deal, particularly for cross-border and activity-diversifying deals and deals completed under weak bank regulatory regimes.
} 
As to uncertainty and opacity, we conjecture that opacity of bank assets may have been relevant during the crisis and therefore that there may have been particular value in the due diligence process carried out by the acquiring bank. Assets in banking are widely recognized to be opaque. Flannery, Kwan and Nimalendran (2010) recognize the increase in bank opacity at the beginning of the financial crisis. The crisis was propagated by the diffusion of mortgage-backed securities that were present in the balance sheets of several banks. Uncertainty about the holdings of such securities may have been an important cause of information asymmetry and a relevant valuation factor. An acquisition implies a careful due diligence that externally certifies the value of the target. This activity is particularly valuable in sectors and at times when investors are more uncertain about the value of assets. Jones, Lee and Yeager (2011) find that revaluations associated with merger announcements in 2000-2006 carry positive information for banks particularly exposed to opaque assets. During the crisis, the due diligence process carried out by acquirers may therefore have been particularly valuable to clarify the relevance of target's low-quality assets and this may have had an impact on returns. A further reason why completion may be a significant event for investors is that there is a positive probability - consistent with the activity of merger arbitrageurs ${ }^{4}$ - that a deal does not materialize in ordinary times, and even more so at a time of financial distress, when information asymmetry and sudden adverse changes could enhance the likelihood to terminate the transaction ${ }^{5}$. Lorenz and Schiereck (2007) find that investors are able to correctly assess the probability of realization already on the announcement day and that they then appreciate the successful closing of the deal providing a premium to the bidder (the reverse holds true in case of termination). Indeed deal closing/termination events take away uncertainty, provide new information about the preliminary purchase price and about unknown financial data which has been learnt during the due diligence.

\footnotetext{
${ }^{4}$ The relevance of merger arbitrage, an investment strategy providing insurance to target firm shareholders against deal failures, has been ascertained by Pulvino et al. (2004) among others.

${ }^{5}$ Between 1990 and 2010 around $5 \%$ of the worldwide announced deals in the banking sector were cancelled with peaks of $12.5 \%$ in a financially advanced country such as Norway.
} 
We find that abnormal returns for bank acquirers are zero on average after announcements but positive after the date of completion. Cross-sectionally, abnormal returns at the announcement date are mainly explained by bank characteristics. Abnormal returns are larger for more efficient banks, banks with higher profitability and with less leverage. Buying a national target and implementing a friendly deal have also a positive impact on abnormal returns. Interestingly, and contrary to what found in previous literature, idiosyncratic volatility is not relevant and paying in cash is bad for abnormal returns. The latter finding runs contrary to the signalling hypothesis and could be due to investors being disappointed by the choice of the acquirer to use cash at times of a credit and liquidity crisis. Furthermore, we find that abnormal returns after completion are explained by several factors usually related to the likelihood of merger termination, among which we find the opacity of the target, the size of the deal, and the effectiveness of the national supervision. The speed of information dissemination after closing is associated with the number of analysts monitoring the acquirer's activity and the size of the deal. Ten-day CARs are related with the precompletion increase in volatility. Importantly, we find that terminated deals have a negative impact on acquirer's abnormal returns, while bank concentration has a positive influence.

The remainder of this paper is organized as follows. Section 2 illustrates the hypothesis related to the variables used herein. Section 3 includes a sample description and a preliminary analysis of the acquirer abnormal returns. Section 4 provides more complete analyses of the relations between acquirer cumulative CAR and other covariates at different time windows. Finally, we discuss the implications of our results and provide concluding remarks in Section 5.

\section{Data and hypotheses.}

Our data ${ }^{6}$ are taken from various sources. The dependent variables are abnormal returns over different windows. Our aim is to explain abnormal returns both at announcement and completion dates. The reason why we look at abnormal returns at completion is due to our study encompassing

\footnotetext{
${ }^{6}$ Appendix A contains definition of the variables as well as the specific source.
} 
the financial crisis time period. During a financial crisis, opacity of bank assets and sudden material changes could imply a higher probability that the due diligence process carried out by potential acquirers may convey a negative result. This may warrant a market reaction after completion. The potential relevance of completions is consistent with the relevance of deal announcements. Especially during a crisis, announcing an acquisition could be regarded as good news if it is interpreted as a signal of financial health. However, after the announcement, uncertainty goes up and is resolved at the time of the closing. Our hypothesis is that completion announcements are value relevant during a financial crisis, especially for opaque targets and in cases where there is a lower probability of completion. To measure opacity, lacking any information on specific categories of loans, we construct a dummy variable (Transparency) representing the availability of information on the target economic conditions. The dummy has a maximum value of four, when information on target economic conditions is fully available, and a minimum of 0 in the opposite case. It scores 1 point for information available on any of the following categories for the ratget; (1) Tier 1, ROE and ROA; (2) EPS growth, Sales per Diluted Share 1 yr Growth; (3) multiple equity ratios (for example, book-market ratio) (4) efficiency ratio.

The likelihood to successfully conclude a deal is enhanced when the acquisition is friendly and the focus is on national targets. Beitel et al. (2003) find that domestic mergers, by signalling higher likelihood of ex ante sinergy (e.g., more cost savings) are both more understandable for capital markets and get easily approved by shareholders. Similarly when a deal is made on a friendly basis it is plausible to expect that the due diligence process will be quicker and reliable. In the paper National is a dummy variable taking the value of one when the acquirer and the target headquarter are located in the same country and Friendly is a dummy variable taking the value of one when the deal is announced to be friendly towards the target's managers.

We also conjecture that speed of information dissemination about M\&A deals is likely to be positively related to the number of analysts monitoring the acquirer's activity and negatively to 
minors deal carried out by less monitored acquirers, so we control for that (Analysts and Minors no coverage) in our regressions.

Asymmetric information is relevant in M\&As. The choice of the payment may reveal private information known by the bidder. Myers and Majluf (1984) argue that, given the access to privileged information by the managers of the bidder firm, cash is chosen as a mean of payment only if the firm's shares are undervalued. There are of course other explanations for the role of the method of payment. From a corporate governance point of view, cash payment is used when acquiring managers have large ownership and highly value firm's control (Amihud et al. 1990). Finally, the use of cash may deter competing offers for the target firm when the cost of collecting information about the target is high (Fishman 1989). It follows that a cash-financed merger attempt enhances the likelihood of a merger completion as also suggested by Branch et al. (2003). ${ }^{7}$ In our analysis, Cash is a dummy variable that takes a value of one when the deal is paid cash or debt and zero otherwise.

We consider idiosyncratic volatility (Volatility) as a proxy for asymmetric information. Moeller et al. (2007) find that idiosyncratic volatility is a powerful proxy for asymmetric information. Our hypothesis is that idiosyncratic volatility during financial crises may also represent uncertainty related to the successful conclusion of the deal. To account for the increase in uncertainty over the completion period we use Delta volatility, equal to the ratio between idiosyncratic volatility from one day after the announcement to one day prior the completion and idiosyncratic volatility from 35 to 5 days before the announcement. If idiosyncratic volatility is priced, its increase should be associated with a decrease in prices.

We use several acquirer characteristics as control variables ${ }^{8}$. Efficiency is defined as the ratio between expenditures and total revenues, $R O E$ is the return on equity, $P B$ is the price to book ratio,

\footnotetext{
${ }^{7}$ Moreover Moeller et al. (2007) find that abnormal returns associated with acquisition of public firms paid for with cash (equity offers) increase (decease) with idiosyncratic volatility. Faccio and Masulis (2005) explain acquisition financing on the basis of the bidder corporate control and the acquirer financial strength. Moeller (2005) shows that cash payments are associated with higher acquisition premiums than are transactions using other methods of payments. Chen et al. (2011) consider the relevance of timing the acquisition announcement and its effect on payment methods.

${ }^{8}$ Bank characteristics are measured at the end of the year before the announcement of the deal.
} 
and Assets is the log of total assets. Various measures of leverage are also considered: tangible equity to asset ratio orthogonalized with respect to size (Equity), the ratio between the sum of short term and long term funding and total assets (Leverage), the debt to equity ratio (Debteq) and an indicator of funding fragility equal to the ratio between the sum of deposits from other banks, other deposits and short term borrowing over total deposits plus money market and short term funding (Fragility). Healthy acquirers are expected to have higher chances to close the deal with a success and this is likely to be acknowledged by market participants. Among the remaining deal's features, Terminated is a dummy variable taking the value of one when deal is not completed; Public is a dummy variable taking the value of one when the target is public, Dummy 0309 takes the value of one if the deal is concluded after March 2009 (i.e when banks start recovering from the losses recorded in end 2007-2008).

The degree of concentration in the banking sector may be relevant. Higher concentration implies fewer effective bidders, which enhance the pricing power of the acquirer (James and Wier, 1987). Moreover banks may use M\&A exactly to achieve pricing power. We use Concentration, defined as the ratio between the assets of the three largest commercial banks to total market asset in the acquirer country as a measure of bank concentration.

It is often claimed that bank acquisitions during a financial crisis may be due to the intervention of the regulator that forces healthy banks to buy troubled organizations. As a proxy for the power of regulators to enforce socially useful acquisitions, we use Official, an index of the power of the commercial bank supervisory agency, including the rights of the supervisor to meet with and demand information from auditors, to force a bank to change the internal organizational structure, to supersede the rights of shareholders, and to intervene in a bank.

Finally, we allow for international differences in corporate governance. Doige at al (2007) suggest that inter-country differences in governance are relevant for financial markets. The impact of Governance indicators in M\&A has recently been studied by Ellis et al (2011) who find that acquirers from countries with better governance gain more from cross border acquisitions. Like 
Ellis et al. (2011) we also use the World Governance Indicators representing the degree of control of corruption, government effectiveness, political stability, regulatory quality, rule of law and voice and accountability. We expect that acquirers with better governance indicators have larger abnormal returns associated with $\mathrm{M} \& \mathrm{~A}$ transactions.

\section{Sample Description and Preliminary Analysis.}

\subsection{Sample description.}

From the inception of the crisis onwards, international flows of M\&A in the banking sector have shrunk considerably with respect to levels reached in 2007. Over the period 2007-2008, the European financial sector recorded 292 announced deals for a total value of $€ 345 \mathrm{bn}$. 2009 saw a steep decline in financial services deal-making to $€ 80 \mathrm{bn}$ (only 49 deals have involved banking targets and, excluding government's activity, the number fell to 11 transactions.) During 2010 financial sector M\&A deal value dropped to €50bn (of which €30bn in banking) due to a sharp reduction in government led transactions which was only partially compensated by the revival of the private sector activity ${ }^{9}$.

This downward trend is mainly due to both the credit crisis that put European banks under funding pressure and the lack of clearly defined national anti-crisis measures. Thus, banks which found themselves in financial difficulty due to lack of liquidity or equity capital were likely become prey to acquirers; banks unscathed by the crisis found themselves in a much stronger position, when considering M\&A activity, given the diminishing number of competitors.

Our sample involves acquisitions of banks (subsidiaries or branches) by acquirer banks whose headquarter is located in EU, Switzerland and Norway. The related information is taken from Bloomberg and limited to deals with announcement and completion - or terminated - date between January 2007- November 2010. By limiting the analysis to deals valued higher than $15 \mathrm{mln}$ euro ${ }^{10}$ and involving public acquirers we restrict the sample to 131 completed and 8 terminated deals, for

\footnotetext{
${ }^{9}$ Source PWC European Financial services M\&A insight several issues (2008-2011)

${ }^{10}$ In case of undisclosed value ( $28 \%$ of the sample) the estimated value of the deal is higher or equal to $€ 15 \mathrm{mln}$.
} 
a total of 139 observations. Among the largest deals included in our database it is worth mentioning the acquisition of Capitalia by Unicredit SpA (announced deal value $€ 21.935$ bn), the attempted acquisitions of ABN Amro by Barclays (€67.824bn) and of Banco Comercial Portugues SA by Banco BPI SA (€11.574bn); the acquisition of Banca Antonveneta SpA by Monte dei Paschi di Siena ( $€ 9$ bn) and the merger between Hypo Real Estate Holding AG and Depfa Bank PLC ( $€ 5.622 \mathrm{bn})$, To retrieve returns on individual equities and market indices we use Datastream (Thomson Reuters). The majority of our sample (56\%) includes privately held targets. Acquirer and target characteristics (financial ratios) are computed on data available from Bankscope. Nationwide features, such as legal origin and governance index are obtained from World Governance Indicators 2010 and Andrei Sleifer's database available on his webpage.

\section{<INSERT TABLE 1 AROUND HERE>}

Table 1 reports descriptive features of the transactions under exam. The average value of transactions included in our sample is $€ 1,682 \mathrm{mn}^{11}$. The difference between average values in the two sub-periods $2007-2008$ and $2009-2010$ is not statistically significant. Completion time is not statistically different in the two sub-periods. In unreported results, we however find that at the peak of the crisis (July 2007- December 2008), deals took a significantly longer time to be completed than deals concluded before July 20007 or after December 2008 (108.98 vs 54.87 days) ${ }^{12}$. It is not hard to think of several potential explanations for the latter finding, for example funding problems and/or a more difficult due diligence assessment related to a combination of asset opacity and disruptions in prices of assets like loans and mortgage baked securities.

Over the sample, most transactions $(54.68 \%)$ refer to firms belonging to the same business subgroup $^{13}$, are paid in cash $(50.36 \%)$ and are proposed on a friendly basis $(60.43 \%)$. Overall, only

\footnotetext{
${ }^{11}$ The average deal value without the terminated offer of Barclays amounts to $€ 1,233 \mathrm{mn}$.

${ }^{12}$ The $t$ test of mean difference for the days between announcement and completion rejects the null of mean equality at any probability level greater than $0.09 \%$ (student $\mathrm{t}=-3.41$ ).

13 For acquirer banks, the subgroups included in the group "banks" are: commercial banks non US; cooperative banks; diversified banking institutions; mortgage banks; regional banks non US. As for targets the subgroups included in the
} 
in $36 \%$ of deals, acquirers and targets are located in the same country (50\% in the second subperiod) and - in the majority of cases - targets are located outside the EU.

\section{$<$ INSERT TABLE 2 AROUND HERE >}

Table 2 provides the geographic dispersion of acquirers and targets. Bidders located in France, Germany, Italy, Spain and the UK were the most active during the period 2007-2010. Italy, Germany, Spain, Ukraine and Russia are the five countries where most targets came from. Italy is the country with the most frequent domestic transactions followed by Germany, France and Spain. The UK has the highest number of deals involving targets in "other countries", a label that refers to a group of several emerging countries.

\subsection{Evidence on cumulative abnormal returns.}

In order to examine the effect of M\&As on the acquirer/target share value most event studies rely on the concept of abnormal returns defined as the raw stock return minus some required return based on a model such as the CAPM or a simpler Market index. The focus here is on Cumulative Abnormal Returns (CARs) and on Average Cumulative Abnormal Returns (ACARs) around the Announcement or Completion date. They are computed - at different window-size - using the Eurostoxx bank index as market index.

Table 3 shows that abnormal returns are significantly positive around the completion date if we consider windows starting five or ten days before completion and ending ten days after completion. For example in the twenty days centred around the event, average cumulative abnormal returns amount to a very large $2.3 \%$. Interestingly, abnormal returns of a similar magnitude are observed over the twenty days after the event. Abnormal returns are not significantly different from zero for windows of five days or less. As we will show in our cross-sectional analyses, this long reaction lag can be explained by delays in the production of information

group banks are: commercial banks non US; commercial banks US; cooperative banks; diversified banking institutions; money center banks, mortgage banks; regional banks non US; special purpose banks. 
At announcement dates, cumulative abnormal returns are statistically insignificant. This can be coherent with a situation where acquisitions are partly motivated by exploiting opportunities on the part of stronger banks and partly induced by regulators actions that try to preserve the stability of the banking system. The statistical relevance of abnormal returns for windows $[-10,+10]$ and [$10,+5]$ is mainly due to statistically significant and on average positive abnormal returns for the window $[-10,-5]$. This may be interpreted as information leakage related to insiders.

\section{$<$ INSERT TABLE 3 AROUND HERE $>$}

We implement a multivariate cross-sectional regression analysis where the dependent variable is the abnormal return of the bidders. The variables are defined in the appendix and their summary statistics are contained in Table 4. We winsorize bank-level explanatory variables and volatility measures at the $1 \%$ and $99 \%$ levels.

\section{$<$ INSERT TABLE 4 AROUND HERE >}

In our cross section OLS-regressions we control for fixed effects, for multi-collinearity using variance inflation factors (VIF) and tolerances for individual variables and for a non-diagonal covariance matrix by robust standard errors.

\section{The determinants of Cumulative Abnormal Returns.}

\subsection{CARs around announcement}

We use the window $[-1,+1]$ to compare our results with the extant literature. Table 5 reports the results of several specifications and highlights that acquirers' financial strength and deal features have the most relevant role and are able to explain around $20 \%$ of the dependent variable variance.

\section{< INSERT TABLE 5 AROUND HERE>}

Contrary to what happens in most of the existing literature, the sign of cash is negative across all the specifications. An acquirer paying by cash has a return of over $-1 \%$ less than an acquirer that does not use cash. Our interpretation is that cash payment depletes the bidder's liquidity buffer in exchange for a risky asset (the ownership of the target). Thus cash payments, by reducing the 
bidder's distance to default (Vallascas and Hegendorff 2011), could produce a negative impact on cumulative abnormal returns, particularly during a crisis when the marginal value of cash is likely to be higher than in normal times. The credit crisis has largely been a liquidity crisis. Many analyses of the crisis have emphasized the run on the funding of banks that relied on short-term finance in the capital markets for a substantial fraction of their financing (see, for instance, Gorton (2010), and Diamond and Rajan (2009)). Our results therefore show that during a liquidity crisis it is therefore negative to use cash to finance an acquisition.

We try to better understand this result by using a dummy for the period August 2008-mid October 2008, corresponding to a period of high liquidity stress on the European interbank market. In unreported results, cash turns out to be negative during the crisis but irrelevant otherwise ${ }^{14}$, coherently with our hypothesis that the crisis has affected the traditional role of the payment method. Some banks could have decided to use cash rather than issuing stocks for good reasons. Banks may have felt that stock prices were depressed and did not provide a correct evaluation of the assets, therefore they prefer to use cash rather than to signal the stock has room to drop farther. Investors themselves may have been cash-constrained during the crisis and therefore not willing to join capital-raising efforts on the part of corporations..

The return on equity and leverage (as represented by Equity) ${ }^{15}$, both interpreted as indicators of financial strength, have a positive impact on CARs. Beltratti and Stulz (2011) also find that leverage was an important factor for the determination of bank stock returns during the crisis, with banks with higher tangible equity better resisting to the crisis. Investors may have concluded that banks with better capital and profitability were in a better position to exploit synergies arising from the acquisition.

Deal features also contribute significantly to explaining the variance of the dependent variable. Friendly acquisitions and transactions where both the acquirer and the target are located in the same

\footnotetext{
14 Indeed only the dummy variable representing the liquidity crisis period and its interaction with cash, but not the cash standalone, are significantly different from zero.

${ }^{15}$ In table 5 leverage is computed as the ratio of tangible equity to asset orthogonalized with respect to the bidder's size, as in Vallascas et Hegendorff (2011), but the use of alternative measures (see section 4.3) does not affect the result.
} 
country are positive elements for abnormal returns. Our interpretation is that both factors reduce deal's opacity and enhance the likelihood of success.

Differently from Moeller et al. (2007), idiosyncratic volatility is not relevant. Either idiosyncratic volatility is not a good proxy for asymmetry of information during the crisis or asymmetric information does not play a direct role. Our finding that cash has a negative coefficient is indeed consistent with the latter interpretation. Other control variables that are included in the various specifications of table 5 are not significant.

\subsection{CARs after completion}

We now turn to abnormal returns after completion. We focus on CARs computed at two event windows: the day after the closing $[0,+1]$, to evaluate the direct impact of the news, and ten days after the closing $[0,+10]$ to investigate the forces responsible for the accumulation of highly significant positive abnormal returns displayed in table 3.

Several factors play a role immediately after completion/termination.

\section{$<$ INSERT TABLE 6a AROUND HERE>}

CARs are positively affected by a reversal effect associated with abnormal returns between the announcement and the completion dates, the power of the commercial bank supervisory agency, differences in regulatory quality between acquirer and target country, target's opacity and deal size. Indeed, Caiazza and Pozzolo show that these variables are usually correlated with merger failure. It follows that when a transaction with the previous characteristics is concluded rather than terminated the market perceives this information as a positive piece of news.

The negative sign of Transparency is in line with our conjecture that target's opacity was relevant during the crisis. Investors bid up the prices of acquirers when these succeeded in purchasing opaque targets. On the other hand, investors reacted more strongly when a larger number of analysts study the bank and when the size of the deal is large. It makes sense that reaction is more immediate when there are more analysts and when the deal is more visible in the market. 
For the event window $[0,+10]$, the average cumulative abnormal return for our sample of 139 acquirers is $1.5 \%$, corresponding to an annualized value of $37.5 \%$.

\section{$<$ INSERT TABLE $6 b$ AROUND HERE $>$}

The regressions in table $6 \mathrm{~b}$ generally show that returns after completion are mainly explained by factors that are directly connected to the market environment rather than to acquirer characteristics. The only relevant deal characteristic is the cash dummy which exerts a negative influence on abnormal returns, consistent with the impact at the announcement. It is however puzzling that cash has no significant effect at the $[0,+1]$ window.

Bank concentration of the acquirer is positive and significant. This is easily understandable when the acquirer and the target have the same nationality, as lack of competition implies fewer effective bidders and this enhances the pricing power of the acquirer (James and Wier, 1987). One might wonder why bank concentration should be relevant in cases of international transactions. We conjecture that in these cases cross border acquisitions could be positively appreciated by the market as they signal the bidder's wish to purse growth abroad rather than in an overcrowded domestic market.

The ratio between idiosyncratic volatility in the period between completion and announcement and idiosyncratic volatility before the announcement is significantly positive. Remember from table 4 that idiosyncratic volatility on average significantly goes up from $9.54 \%$ to $10.63 \%$ after the announcement. The increase is temporary, because after completion volatility reverts to the preannouncement level ${ }^{16}$. Regression results in table $6 \mathrm{~b}$ show that a volatility increase predicts a positive abnormal return. This result is consistent with the literature measuring a negative relation between returns and idiosyncratic volatility, see Ang et al. (2006) and Peterson and Smedema (2011). In our sample, high idiosyncratic volatility before completion is associated with a

\footnotetext{
${ }^{16}$ The $\mathrm{F}$ variance test between the variance in the period before the announcement (vol1_idio) and the variance in the period between announcement and completion (vol2_idio) rejects the null hypothesis of equality in $21 \%$ of the cases instead of 5\% (significance level of the test) while the F test between the annualized volatility in the period before the announcement and the variance after completion accepts the null of equality in $92 \%$ of the cases (test with a significance level of 5\%). The results is qualitatively the same applying the test on the log volatility.
} 
contemporaneous low return and low idiosyncratic volatility after completion is associated with a high return. This is coherent with a mispricing story and arbitrageurs demanding a return to correct mispricing, see Shleifer and Vishny (1997).

In addition, Dummy 0309 and Terminated have a significant negative impact on CARs after completion, consistently with the hypothesis that investors only recognize the value creation potential of banks able to bring to success the transaction during time of distress. Indeed deals completed/terminated after March 2009, which marks the recovery of the EU banking sector, are associated to diminishing abnormal returns. Interestingly the deal size and the dummy representing the number of analysts (i.e the accuracy and speed of information dissemination) are not relevant here. On the contrary, the variable representing minor deals (valued less than $250 \mathrm{mln}$ euros) with no coverage by analysts (Minors no coverage) stands out as highly significant, consistent with our conjecture that the time needed to build up a significantly positive abnormal returns is mainly due to delays in information dissemination.

\subsection{Robustness analysis}

We run a variety of robustness tests. We estimate a set of regressions where the dependent variable is regressed on core variables - which are included in every specifications- and all possible combinations of testing variables. The selection of the core variables is somehow arbitrary, being represented by the the explicative factors that show a higher significance level in the original estimation. The reduction of variables considered "core" simply allows to run a larger number of alternative specifications without modifying the interpretation of the exercise.

\section{<INSERT TABLE 7 AROUND HERE>}

In table 7, the columns "percsign" refers to the share of regressions where the coefficient of the corresponding variable is significant at the specified significance level. The results presented in the table confirm both the stability of coefficients' signs (the few cases of changes in sign are 
related to variables that are not significant in the original regressions) and the importance of the variables identified in this paper.

We further investigate the reliability of our results by using a larger spectrum of governance indicators. As to the role of governance and minority shareholder protection indexes, La Porta et al. (1998) claim that common law countries better protect minority shareholders. Hence we consider the following country specific indicators of protection of minority shareholders: revised anti director rights index ${ }^{17}$, legal origin ${ }^{18}$, anti self-dealing index both for targets and acquirers. The inclusion of these explicative variables in the econometric specifications displays an impact on abnormal returns which is not significantly different from zero.

Our results also proved robust to the alternative measures of governance. We experiment both with the remaining five World Governance indicators (degree of control of corruption, government effectiveness, political stability, rule of law and voice and accountability) either separately or as difference between acquirer and target's values and with their arithmetic average (Gover). The related coefficient were not significant whereas all the other regression coefficients were virtually unaffected.

We also use the variable Capital, an index of regulatory oversight of bank capital including indicators for whether the sources of funds that count as regulatory capital can include assets other than cash and government securities, and whether authorities verify the source of capital. However Capital is generally insignificant

Demirguc-Kunt and Huizinga (2010) have investigated the role played by public authorities in bailing out their national financial sectors. This might have been a source of positive abnormal returns, as some banks may have had a weak capital and liquidity position but may have acquired other banks due to the strength implicitly provided by the too-big-too-fail phenomenon. We have

\footnotetext{
${ }^{17}$ Both the origin and the revised anti director rights indices summarize the protection of minority shareholders in the corporate decision-making process, including the right to vote. The general principle behind the construction of the revised anti-director rights index is to associate better investor protection with laws that explicitly mandate, or set as a default rule, provisions that are favorable to minority shareholders.

${ }^{18}$ As expected, legal origin is correlated with the other two indicators. In unreported results, civil law countries present significantly weaker governance indices.
} 
constructed a proxy for public intervention (Debt) which is equal to one when the public debt to GDP ratio between 2006 and 2009 increased at least of 15 percentage points. Debt has no effects on CARs. In addition we have accounted for alternative measure of acquirer strength and size. We estimate equation (1) to (6) in table 5, 6a and $6 \mathrm{~b}$ alternatively using: the debt to equity ratio, our fragility indicator, leverage, the log of the market capitalization (instead of the log of the total asset) and the ratio of the tangible common equity to tangible asset. Once again our conclusions were not substantially affected.

Finally we use abnormal returns constructed using different banking sector index i.e. FTSE World banks and Datastream EU banks. There are no substantial changes to our results as the majority of the estimated coefficient keep the sign and significance patterns of the original specification.

\section{Conclusion.}

We conjecture that there may be particular value to acquisitions implemented during a financial crisis, and that investors, due to substantial uncertainty, may partially react to announcements of acquisitions and provide a premium when the transaction is completed. Consistent with our hypothesis, we find that abnormal returns for bank acquirers are zero on average at the announcements but positive after completion.

We further study the cross-section of abnormal returns. Abnormal returns at announcement dates are mainly explained by bank characteristics. Abnormal returns are larger for more efficient banks, banks with higher profitability and with less leverage. Buying a national target and implementing a friendly deal are also useful characteristics. Interestingly, and contrary to what found in previous literature, idiosyncratic volatility is not significant. Paying in cash is bad for abnormal returns. This runs contrary to the signalling hypothesis and could be due to investors being disappointed by the choice of the acquirer to use cash at times of a credit and liquidity crisis. Investors may also be disappointed by insiders holding control of the company. 
At completion, market reacts positively in cases of opaque targets and strong regulatory environment, presumably to reward the reduction of uncertainty associated with the materialization of the deal. Transactions larger than $€ 1 b n$ and analysts coverage, respectively proxying for visibility and speed of information dissemination, have also a positive impact on CARs at the nearest window. Consistently with the negative idiosyncratic volatility-return relationship highlighted in the literature, we find that abnormal returns measured ten days after completion are larger when volatility goes up the most before completion. Importantly, we find that terminated deals have a negative impact on abnormal returns and that information delays can play a role in explaining the sluggish market reaction.

Overall, it seems that M\&A activity in the banking sector during the financial crisis was indeed different. Investors attached significant uncertainty to completion of deals, and rewarded successful acquisitions with delayed abnormal returns. These findings are relevant for studies of M\&A spanning longer time periods, possibly involving one or more financial crises. If M\&As carried out during normal times behave differently than M\&As carried out during crises, then empirical studies should be careful in considering all observations together. Our research only considers the banking sector, but it would be interesting to extend it to other sectors. Evidence presented by Cai, Song and Walkling (2011) on long-run anticipation also shows the usefulness of linking M\&A activity to the economic environment. The more general implication of our study is that the value attached by investors to acquisitions may depend on the state of the economy. Researchers should therefore avoid mixing observations coming from different regimes. 


\section{References}

Acharya, Viral V., Hyun Song Shin, and Tanju Yorulmazer, 2011, Crisis resolution and bank liquidity, Review of Financial Studies, 24, 2166-2205.

Amihud, Yakov, Baruch Lev and Nickolaos G. Travlos, 1990, Corporate Control and the Choice of Investment Financing: The Case of Corporate Acquisitions, The Journal of Finance 45, 603-616.

Ang, Andrew, Robert J. Hodrick, Y. Xing, and X. Zhang, 2006, The cross-section of volatility and expected stock returns, Journal of Finance, 61, 259-299.

Beitel, Patrick, Dirk Schiereck and Mark Wahrenburg, 2004, Explaining M\&A success in European banks, European Financial Management 10, 109-139.

Beltratti, Andrea, and René M. Stulz, 2011, The credit crisis around the globe: Why did some banks perform better?, Journal of Financial Economics, forthcoming.

Berger, Allen, and Christa Bouwman, 2009, Bank Liquidity Creation, The Review of Financial Studies 22, 3779-3837.

Branch, Ben, and Yang Taewon, 2003, Predicting successful takeovers and risk arbitrage, Quarterly Journal of Business and Economics Winter/Spring, 3-18.

Cai, Jie, Moon H. Song, and Ralph A. Walkling, 2011, Anticipation, acquisitions, and bidder returns: Industry shocks and the transfer of information across rivals, Review of Financial Studies, 24, 22422285 .

Caiazza Stefano and Alerto F. Pozzolo, 2011, Le determinanti dell'abbandono nelle operazioni di fusione e acquisizione nel settore bancario, XVI Rapporto Fondazione Rosselli, Edibank, 315-331.

Campa, José Manuel, and Ignacio Hernando, 2006, M\&A Performance in the European Financial Industry, Journal of Banking and Finance 30, 3367-3392.

Chen, Sheng-Syan, Robin K. Chou, and Yun-Chi Lee, 2011, Bidders' strategic timing of acquisition announcements and the effects of payment method on target returns and competing bids, Journal of Banking and Finance, 35, 2341-2354.

DeYoung, Robert, Douglas D. Evanoff, and Philip Molyneux, 2009, Mergers and acquisitions of financial institutions: E review of the post-2000 literature, Journal of Financial Services Research, 36, 87-110.

Demirgüç-Kunt, Asli and Harry Huizinga, 2010, Are Banks Too Big to Fail or Too Big to Save? International Evidence from Equity Prices and CDS Spreads, Policy Research Working Paper, 5360, The World Bank.

Diamond, Douglas W., and Raghuram Rajan, 2009, The Credit Crisis: Conjectures about Causes and Remedies, American Economic Review,99, 606-10.

Doidge, Craig. G.Andrew Karolyi, and René Stulz, 2007, Why Do Countries Matter So Much for Corporate Governance?, Journal of Financial Economics 86, 1-39.

Emmons, William, Alton Gilbert, and Timothy Yeager, 2004, Reducing the Risk at Small Community Banks: Is It Size or Geographic Diversification That Matters?, Journal of Financial Services Research 25, 259-281.

Ellis, Jesse, Sara Moeller, Frederik Schlingemann and René Stulz, 2011, Globalization, Governance and the Return of Cross Border Acquisitions, Dice Center WP 2011-1. 
Faccio, Mara and Ronald W. Masulis, 2005, The Choice of Payment Method in European Mergers and Acquisitions, Journal of Finance, 60,1345-1388

Fishman, Michael J., 1989, Preemptive Bidding and the Role of the Medium of Exchange in Acquisitions. Journal of Finance 44, 41-57.

Flannery, Mark J., Simon H. Kwan and Mahendrarajah Nimalendran, 2010, The 2007-09 Financial Crisis and Bank Opaqueness, Federal Reserve Bank of San Francisco, Working Paper Series 2010-27

Gorton Gary B., 2010, Questions and Answers about the Financial Crisis, NBER Working Paper Series, Working Paper 15787.

Group of Thirty, 2009, Financial Reform: A Framework for Financial Stability Special Report: Washington DC.

Hansen, Robert G., 1987, A Theory for the Choice of Exchange Medium in Mergers and Acquisitions, Journal of Business 60, 75-95.

Hankir, Yassin, Rauch Christian and Marc P. Umber, 2011, Bank M\&A: A Market Power Story?, Journal of Banking and Finance, 35, pp. 2341-2354.

Hughes, Joseph P., William W. Lang, and Loretta J. Mester, 1999, The dollars and sense of bank consolidation, Journal of Banking and Finance 23, 291-324.

James, Christopher M. and Peggy Wier, 1987, Returns to Acquirers and Competition in the Acquisition Market: the Case of Banking, The Journal of Political Economy 95, 355-370.

Jones, Jeffrey, Wayne Y. Lee and Timothy Yeager, 2011 Opaque Banks, Price Discovery, and Financial Instability, Working Paper (May 11, 2011). Available at SSRN: http://ssrn.com/abstract=1458575

Karceski, Jason, Steven Ongena and David C. Smith, 2005, The Impact of Bank Consolidation on Commercial Borrower Welfare, Journal of Finance 60, 2043-2082.

Koetter, Michael, Jaap W.B. Bos, Frank Heid, James W. Kolari, Clemens J.M. Kool and Daniel Porath, 2007, Accounting for Distress in Bank Mergers, Journal of Banking and Finance 31, 3200-3217.

La Porta, Rafael, Florencio Lopez-de-Silanes, Andrei Shleifer and Robert W. Vishny, 1998, Law and finance, Journal of Political Economy 106, 1113-1155.

Lorenz, Johannes-T. and Dirk Schiereck, 2007 Completed versus cancelled banking M\&A transactions in Europe, Working Paper.

Mitchell, Mark, Todd Pulvino and Erik Stafford, 2004, Price pressure around mergers, Journal of Finance, 59, 31-63.

Moeller, T., 2005, Let's make a deal! How shareholder control impacts merger payoffs, Journal of Financial Economics, 76, 167-190.

Moeller, Scott and Anna Faelton, 2009, The Good, the Bad and the Ugly: A Guide to M\&A in distressed times Cass Business School, M\&A Research Centre.

Moeller, Sara B., Frederik P. Schlingemann, and René M. Stulz, 2007, How do diversity of opinion and information asymmetry affect acquirer returns? Review of Financial Studies, 20, 2047-2078.

Myers, Stewart and Nicholal S. Majluf, 1984, Corporate financing and investment decisions when firms have information that investors do not have, Journal of Financial Economics 13, 187-221. 
Netter, Jeffry, Mike Stegemoller and M. babajide Wintoki, 2011, Implications of data screens on merger and acquisition analysis: A large sample study of mergers and acquisitions from 1992 to 2009, Review of Financial Studies, 24, 2200-2243.

Peterson, David R., and Adam R. Smedema, 2011, The return impact of realized and expected idiosyncratic volatility, Journal of Banking and Finance, 35, 2547-2558.

Shleifer, Andrew, and Robert W. Vishny, 1997, The limits of arbitrage, Journal of Finance, 52, 35-55.

Spyrou, Spyros and Georgia Siougle, 2010, Stock price reaction to M\&A announcements: Evidence from the London Stock Exchange, Journal of Money, Investment and Banking 16, 29-45.

Vallascas, Francesco, and Jens Hegendorff, 2011, The Impact of European Bank Mergers on Bidder Default Risk, Journal of Banking and Finance 35, 902-915.

van Lelyveld, Iman and Klaas Knot, 2009, Do Financial Conglomerates Create or Destroy Value? Evidence for the EU, Journal of Banking and Finance 33, 2312-2321. 
Table 1. M\&As transactions: deals characteristics

\begin{tabular}{|c|c|c|c|c|c|c|}
\hline & \multicolumn{2}{|c|}{$\begin{array}{l}\text { Termination/ } \\
\text { completion } \\
\text { Year }\end{array}$} & \multirow[b]{2}{*}{ Total } & \multirow[b]{2}{*}{ Max } & \multirow[b]{2}{*}{ Min } & \multirow[b]{2}{*}{ Stdev } \\
\hline & $\begin{array}{l}2007- \\
2008\end{array}$ & $2009-2010$ & & & & \\
\hline \# observations & 93 & 46 & 139 & & & \\
\hline $\begin{array}{l}\text { Average Days between announcement } \\
\text { and completion (or termination) }\end{array}$ & 85.20 & 90.04 & 86.80 & 626 & 1 & 95.45 \\
\hline Average Value* EUR millions & 2171 & 629 & 1682 & $67824^{+}$ & 15 & 7082 \\
\hline Average percentage sought & 61.11 & 49.08 & 57.13 & 100 & 0 & 39.51 \\
\hline Average percentage owned & 16.12 & 25.15 & 19.11 & 98 & 0 & 31.87 \\
\hline$\%$ deals in same subgroup** & 58.06 & 47.83 & 54.68 & & & \\
\hline$\%$ deals national $* * *$ & 29.03 & 50.00 & 35.97 & & & \\
\hline$\%$ of cash deal & 62.89 & 45.95 & 50.36 & & & \\
\hline$\%$ public target & 48.38 & 34.78 & 43.88 & & & \\
\hline$\%$ target located in EU countries & 45.18 & 47.83 & 46.08 & & & \\
\hline$\%$ friendly deals & 68.82 & 43.48 & 60.43 & & & \\
\hline
\end{tabular}

Note:

* only disclosed deal

** where the target and the acquirer belong to the same subgroup. For acquirer banks, the subgroups included in the group "banks" are: commercial banks non US; cooperative banks; diversified banking institutions; mortgage banks; regional banks non US. As for targets the subgroups included in the group banks are: commercial banks non US; commercial banks US; cooperative banks; diversified banking institutions; money center banks, mortgage banks; regional banks non US; special purpose banks.

*** national indicates that target and acquirer headquarters are in the same country.

+ it refers to the 2007 terminated deal involving Barclays and ABN Amro, without it the max deal value is $€ 21.35 \mathrm{bn}$. 
Table 2. M\&As transactions: geographic scatter

Acquirer country

Target country

AU BE BR UK CA CH CZ DE FR GE GR IR IT JP LAT LU NE NO PO PT RO RU SE SLK SP SW ST TU UKR US others Total

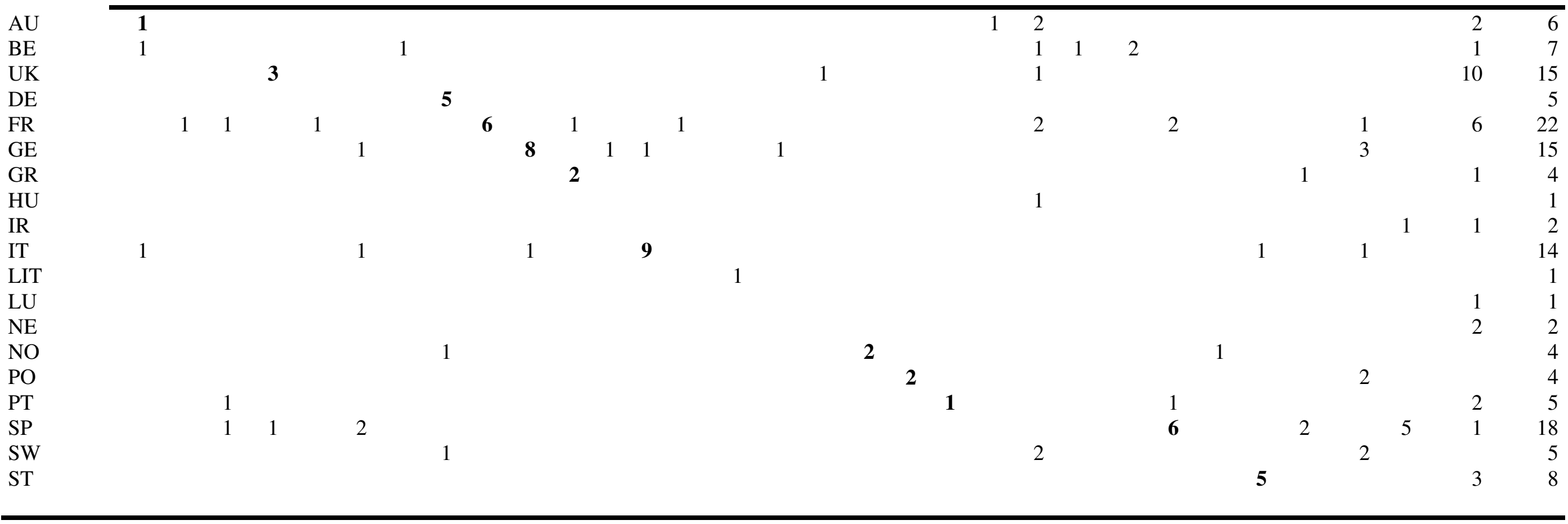

$\begin{array}{lllllllllllllllllllllllllllllllllllllllll}\text { Total } & 3 & 1 & 3 & 4 & 1 & 4 & 1 & 7 & 6 & 9 & 3 & 1 & 10 & 1 & 1 & 1 & 1 & 2 & 2 & 1 & 1 & 9 & 1 & 2 & 9 & 1 & 6 & 3 & 9 & 6 & 30 & 139\end{array}$

Note:

AU (Austria); BE (Belgium); BR(Brazil); CA(Canada); CH(China); CZ(Czech Republic); DE (Denmark); FR(France); GE(Germany); GR(Greece); HU(Hungary); IR(Ireland); IT(Italy); JP(Japan); LAT(Latvia); LIT (Lithuania); LU(Luxemburg); NE(Netherland); NO(Norway); PO (Poland); PT(Portugal); RO (Romania); RU (Russian Republic); SE (Serbia); SLK(Slovakia) SP(Spain); SW(Sweden); ST (Switzerland); TU (Turkey); UK (United Kingdom); UKR (Ukraine);US (United States). 
Table 3. ACARs and CARs statistical description

\begin{tabular}{|l|r|r|r|r|r|}
\hline $\begin{array}{l}\text { Around } \\
\text { announcement }\end{array}$ & \multicolumn{1}{l|}{ Mean } & Std. Dev. & \multicolumn{1}{l|}{ Min } & Max & T test stat \\
\hline ACAR[-10,+10] & 0.0098961 & 0.070492 & -0.1766288 & 0.2634333 & $1.6551^{*}$ \\
ACAR[-10,+5] & 0.0097135 & 0.0689196 & -0.1312673 & 0.3655919 & $1.6617^{*}$ \\
ACAR[-10,-5] & 0.0090970 & 0.0391706 & -0.0677297 & 0.1876822 & $2.7381^{* * *}$ \\
ACAR[-5,+10] & -0.0005435 & 0.0509233 & -0.1452844 & 0.1473456 & -0.12580 \\
ACAR[-5,+5] & -0.0007261 & 0.0539369 & -0.1408297 & 0.2745465 & -0.15870 \\
ACAR[-1,+1] & 0.0008042 & 0.0281737 & -0.0823943 & 0.0921893 & 0.33650 \\
ACAR[0,+5] & 0.002386 & 0.0403558 & -0.0823813 & 0.2176707 & 0.69700 \\
\hline Around & Mean & Std. Dev. & Min & Max & T test stat \\
completion & & & & & \\
\hline ACAR[-10,+10] & 0.0232098 & 0.0785951 & -0.1815986 & 0.2737239 & $3.4816^{* * *}$ \\
ACAR[-5,+10] & 0.0154313 & 0.0629223 & -0.1137862 & 0.2651467 & $2.8914^{* * *}$ \\
ACAR[-5,+5] & 0.0062729 & 0.0519747 & -0.0988714 & 0.1597723 & 1.4229 \\
ACAR[-1,+1] & -0.0003293 & 0.0271342 & -0.1515720 & 0.109283 & -0.1431 \\
ACAR[0,+1] & 0.0000642 & 0.0214482 & -0.0812644 & 0.0876386 & 0.03530 \\
ACAR[0,+5] & 0.0072923 & 0.0375289 & -0.0854738 & 0.1516918 & $2.2909^{* *}$ \\
ACAR[0,+7] & 0.0108452 & 0.0425952 & -0.0881651 & 0.1518328 & $3.0018^{* * *}$ \\
ACAR[0,+10] & 0.0151637 & 0.0479454 & -0.1017041 & 0.1900894 & $3.7288^{* * *}$ \\
ACAR[0,+20] & 0.0238088 & 0.0686559 & -0.2087239 & 0.2498289 & $4.0885^{* * *}$ \\
\hline
\end{tabular}

*Significance level 10\%;**significance level 5\%;*** significance level $1 \%$. 
Table 4. Summary statistics

\begin{tabular}{|c|c|c|c|c|c|}
\hline Exogenous Variables & Obs & Mean & Std. Dev. & Min & Max \\
\hline Abn returns_ac & 139 & 0.0003 & 0.0045 & -0.0098 & 0.0272 \\
\hline Delta volatility & 139 & 1.2334 & 0.6263 & 0.2642 & 3.2751 \\
\hline Volatility & 139 & 10.0843 & 5.9249 & 2.3213 & 38.0855 \\
\hline Efficiency & 139 & 63.9070 & 22.4340 & 27.7300 & 140.5900 \\
\hline Equity & 119 & $-3.64 \mathrm{e}-21$ & 0.0010 & -0.0010 & 0.0030 \\
\hline Assets & 132 & 18.6810 & 1.9830 & 13.3130 & 21.8630 \\
\hline $\mathrm{Pb}$ & 134 & 1.4180 & 0.7500 & 0.0500 & 4.0300 \\
\hline Roe & 132 & 11.3650 & 10.4120 & -36.7120 & 32.7200 \\
\hline Leverage & 119 & 0.7178 & 0.2412 & 0.0322 & 0.9333 \\
\hline Lmktcap & 128 & 9.3475 & 2.1098 & 3.8308 & 12.2589 \\
\hline Teq & 131 & 19.7449 & 29.9484 & 0.9 & 100 \\
\hline Debteq & 118 & 7.4612 & 10.3905 & 0.1800 & 51.9100 \\
\hline Fragility & 118 & 48.0014 & 26.3737 & 4.0800 & 100 \\
\hline Concentration & 139 & 0.7030 & 0.1890 & 0.2730 & 1 \\
\hline Capital & 139 & 6.2380 & 1.9800 & 2 & 9 \\
\hline Official & 139 & 9.2880 & 2.2660 & 5 & 14 \\
\hline Anti director rights & 139 & 3.4930 & 1.0460 & 2 & 5 \\
\hline Anti self-dealing & 139 & 0.4270 & 0.2060 & 0.1810 & 0.9500 \\
\hline Delta regulatory quality & 139 & 0.6187 & 0.8717 & -0.7798 & 2.4693 \\
\hline Gover_ta & 139 & 0.5771 & 0.8729 & -1.0047 & 1.9206 \\
\hline Gover & 139 & 1.2335 & 0.3729 & 0.5310 & 1.8372 \\
\hline
\end{tabular}

Note: see the Appendix for variable descriptions and data sources 
Table 5. Cross sectional OLS regression bidder CAR $[1,+1]$ around the announcement date

Robust standard error and Student t, bank-level variables and volatility measures are winzorized at $1 \%$ and $99 \%$ level.

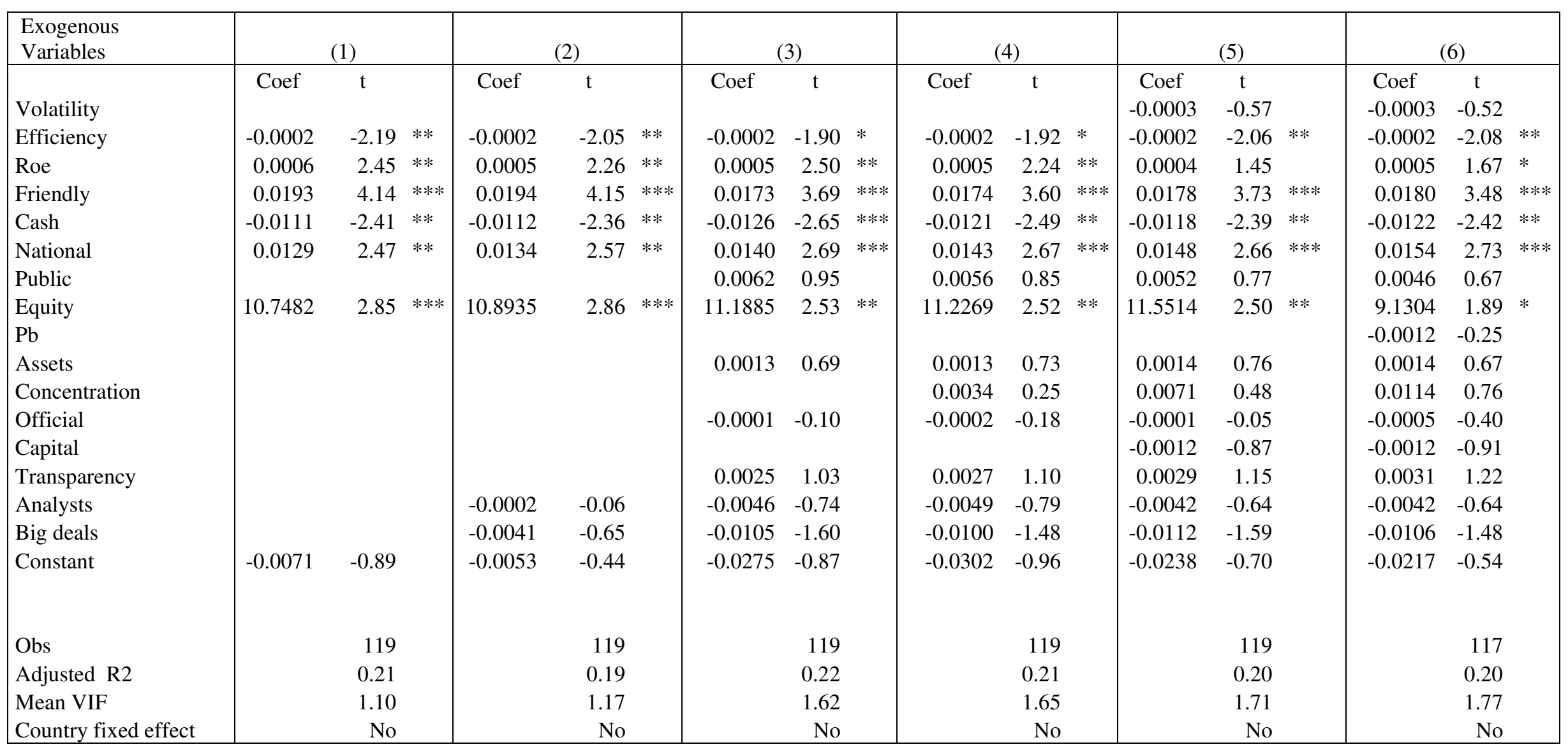

*Significance level 10\%;**significance level 5\%;*** significance level 1\%. 
Table 6a. Cross sectional OLS regression for bidder CAR $[0,+1]$ around the completion date.

Robust standard errors and Student t, bank-level variables and volatility measures are winzorized at $1 \%$ and $99 \%$ level

\begin{tabular}{|c|c|c|c|c|c|c|c|c|c|c|c|c|c|c|c|c|c|}
\hline \multirow{2}{*}{$\begin{array}{l}\text { Exogenous Variables } \\
\text { Delta volatility }\end{array}$} & \multicolumn{3}{|c|}{$(1)$} & \multicolumn{3}{|c|}{$(2)$} & \multicolumn{3}{|c|}{ (3) } & \multicolumn{3}{|c|}{ (4) } & \multicolumn{2}{|c|}{$(5)$} & \multicolumn{3}{|c|}{$(6)$} \\
\hline & $\begin{array}{l}\text { Coef } \\
-0.0020\end{array}$ & $\begin{array}{c}\mathrm{t} \\
-0.87\end{array}$ & & $\begin{array}{c}\text { Coef } \\
-0.0026\end{array}$ & $\begin{array}{c}\mathrm{t} \\
-0.99\end{array}$ & & $\begin{array}{l}\text { Coef } \\
-0.0026\end{array}$ & $\begin{array}{c}\mathrm{t} \\
-0.96\end{array}$ & & $\begin{array}{l}\text { Coef } \\
-0.0025\end{array}$ & $\begin{array}{c}\mathrm{t} \\
-0.85\end{array}$ & & $\begin{array}{l}\text { Coef } \\
-0.0027\end{array}$ & $\begin{array}{c}\mathrm{t} \\
-0.90\end{array}$ & $\begin{array}{l}\text { Coef } \\
-0.0025\end{array}$ & $\begin{array}{c}\mathrm{t} \\
-0.80\end{array}$ & \\
\hline Abn returns_ac & -0.6540 & -2.87 & $* * *$ & -0.5749 & -2.38 & $* *$ & -0.5917 & -2.23 & $* *$ & -0.6834 & -2.40 & $* *$ & -0.6528 & $-2.30 * *$ & -0.7135 & -2.32 & $* *$ \\
\hline Efficiency & & & & & & & & & & $5.5 \mathrm{E}-05$ & 0.67 & & 5E-05 & 0.61 & 3.7E-05 & 0.43 & \\
\hline Friendly & & & & & & & & & & & & & & & 0.0035 & 0.93 & \\
\hline Cash & & & & & & & & & & & & & & & -0.0009 & -0.24 & \\
\hline National & 0.0027 & 0.62 & & 0.0025 & 0.60 & & 0.0024 & 0.58 & & 0.0025 & 0.60 & & 0.0025 & 0.60 & 0.0027 & 0.64 & \\
\hline Public & & & & & & & & & & & & & -0.0029 & -0.51 & -0.0031 & -0.55 & \\
\hline $\mathrm{Pb}$ & & & & & & & & & & 0.0043 & 1.15 & & 0.0044 & 1.17 & 0.0040 & 1.04 & \\
\hline Concentration & & & & -0.0133 & -1.10 & & -0.0136 & -1.07 & & -0.0180 & -1.36 & & -0.0177 & -1.33 & -0.0178 & -1.29 & \\
\hline Official & 0.0016 & 1.70 & $*$ & 0.0020 & 1.81 & $*$ & 0.0020 & 1.80 & $*$ & 0.0019 & 1.55 & & 0.0019 & 1.52 & 0.0017 & 1.37 & \\
\hline Terminated & & & & 0.0060 & 1.39 & & 0.0060 & 1.38 & & 0.0041 & 0.85 & & 0.0041 & 0.85 & 0.0040 & 0.83 & \\
\hline Dummy 0309 & & & & & & & 0.0005 & 0.13 & & 0.0046 & 0.75 & & 0.0044 & 0.72 & 0.0051 & 0.83 & \\
\hline Transparency & -0.0040 & -2.08 & $* *$ & -0.0036 & -2.15 & $* *$ & -0.0036 & -2.18 & $* *$ & -0.0037 & -2.25 & $* *$ & -0.0030 & -1.29 & -0.0031 & -1.38 & \\
\hline Analysts & 0.0047 & 1.65 & $*$ & 0.0050 & 1.74 & $*$ & 0.0050 & 1.71 & $*$ & 0.0058 & 1.91 & $*$ & 0.0057 & $1.84 *$ & 0.0057 & 1.79 & $*$ \\
\hline Big deals & 0.0129 & 2.70 & $* * *$ & 0.0112 & 2.42 & $* *$ & 0.0112 & 2.37 & $* *$ & 0.0123 & 2.49 & $* *$ & 0.0126 & $2.51 * *$ & 0.0130 & 2.53 & $* *$ \\
\hline Delta regulatory quality & 0.0054 & 1.98 & $* *$ & 0.0055 & 2.05 & $* *$ & 0.0055 & 2.04 & $* *$ & 0.0064 & 2.20 & $* *$ & 0.0062 & $2.14 * *$ & 0.0061 & 2.11 & $* *$ \\
\hline Constant & -0.0160 & -1.28 & & -0.0103 & -0.88 & & -0.0103 & -0.88 & & -0.0182 & -1.22 & & -0.0178 & -1.20 & -0.0167 & -1.06 & \\
\hline Obs & & 139 & & & 139 & & & 139 & & & 134 & & & 134 & & 134 & \\
\hline Adjusted R2 & & 0.07 & & & 0.07 & & & 0.07 & & & 0.07 & & & 0.06 & & 0.06 & \\
\hline Mean VIF & & 1.24 & & & 1.27 & & & 1.31 & & & 1.39 & & & 1.54 & & 1.54 & \\
\hline Country fixed effect & & No & & & No & & & No & & & No & & & No & & No & \\
\hline
\end{tabular}

*Significance level 10\%;**significance level 5\%;*** significance level 1\%. 
Table $\mathbf{6 b}$ Cross sectional OLS regression for bidder CAR $[0,+10]$ around the completion date.

Robust standard errors and Student t, bank-level variables and volatility measures are winzorized at $1 \%$ and $99 \%$ level

\begin{tabular}{|c|c|c|c|c|c|c|c|c|c|c|c|c|c|c|c|c|c|c|}
\hline \multirow[t]{2}{*}{ Exogenous Variables } & \multicolumn{3}{|c|}{$(1)$} & \multicolumn{3}{|c|}{$(2)$} & \multicolumn{3}{|c|}{ (3) } & \multicolumn{3}{|c|}{ (4) } & \multicolumn{3}{|c|}{$(5)$} & \multicolumn{3}{|c|}{$(6)$} \\
\hline & Coef & $\mathrm{t}$ & & Coef & $\mathrm{t}$ & & Coef & $\mathrm{t}$ & & Coef & $\mathrm{t}$ & & Coef & $\mathrm{t}$ & & Coef & $\mathrm{t}$ & \\
\hline Delta volatility & 0.0222 & 3.16 & $* * *$ & 0.0212 & 2.88 & $* *$ & 0.0213 & 2.85 & $* *$ & 0.0213 & 2.79 & $* * *$ & 0.0211 & 2.67 & $* * *$ & 0.0168 & 2.16 & $* *$ \\
\hline Abn returns_ac & & & & & & & -0.1049 & -0.18 & & -0.1970 & -0.32 & & -0.1766 & -0.28 & & -0.1758 & -0.27 & \\
\hline Efficiency & -0.0003 & -1.93 & $*$ & -0.0003 & -1.91 & $*$ & -0.0003 & -1.82 & $*$ & -0.0003 & -1.70 & $*$ & -0.0003 & -1.72 & $*$ & -0.0002 & -1.43 & \\
\hline Friendly & & & & & & & & & & -0.0038 & -0.47 & & -0.0037 & -0.46 & & -0.0024 & -0.28 & \\
\hline Cash & -0.0193 & -2.21 & $* *$ & -0.0199 & -2.23 & $* *$ & -0.0188 & -2.07 & $* *$ & -0.0205 & -2.27 & $* *$ & -0.0206 & -2.27 & $* *$ & -0.0153 & -1.69 & $*$ \\
\hline National & & & & & & & & & & -0.0107 & -1.05 & & -0.0107 & -1.04 & & -0.0089 & -0.84 & \\
\hline Public & & & & & & & & & & & & & -0.0029 & -0.34 & & -0.0024 & -0.28 & \\
\hline Assets & & & & & & & & & & & & & & & & 0.0006 & 0.20 & \\
\hline Concentration & 0.0389 & 1.87 & $*$ & 0.0404 & 1.91 & $*$ & 0.0414 & 1.95 & $*$ & 0.0391 & 1.84 & $*$ & 0.0393 & 1.85 & $*$ & 0.0434 & 1.94 & $*$ \\
\hline Terminated & -0.0206 & -2.59 & $* *$ & -0.0243 & -2.35 & $*$ & -0.0225 & -2.08 & $*$ & -0.0222 & -2.12 & $*$ & -0.0222 & -2.12 & $* *$ & -0.0196 & -1.86 & $*$ \\
\hline Dummy 0309 & -0.0175 & -2.15 & $* *$ & -0.0171 & -2.07 & $* *$ & -0.0181 & -1.97 & $* *$ & -0.0163 & -1.72 & $*$ & -0.0165 & -1.73 & $*$ & -0.0183 & -1.58 & \\
\hline Transparency & & & & & & & -0.0030 & -0.88 & & -0.0025 & -0.74 & & -0.0018 & -0.49 & & -0.0037 & -0.95 & \\
\hline Analysts & & & & 0.0021 & 0.34 & & 0.0038 & 0.61 & & 0.0029 & 0.48 & & 0.0029 & 0.46 & & 0.0044 & 0.50 & \\
\hline Big deals & & & & 0.0089 & 0.72 & & 0.0128 & 0.99 & & 0.0122 & 0.94 & & 0.0125 & 0.96 & & 0.0149 & 1.07 & \\
\hline Delta regulatory quality & & & & & & & 0.0015 & 0.32 & & -0.0012 & -0.22 & & -0.0013 & -0.23 & & 0.0011 & 0.17 & \\
\hline Minors nocoverage & 0.0189 & 2.01 & $* *$ & 0.0221 & 2.15 & $* *$ & 0.0221 & 2.11 & $* *$ & 0.0228 & 2.16 & $* *$ & 0.0229 & 2.16 & $* *$ & 0.0179 & 1.64 & $*$ \\
\hline Constant & -0.0125 & -0.58 & $*$ & -0.0174 & -0.84 & & -0.0160 & -0.73 & & -0.0068 & -0.29 & & -0.0066 & -0.28 & & -0.0186 & -0.35 & \\
\hline Obs & & 139 & & & 139 & & & 139 & & & 139 & & & 139 & & & 132 & \\
\hline Adjusted R2 & & 0.14 & & & 0.13 & & & 0.11 & & & 0.11 & & & 0.10 & & & 0.07 & \\
\hline Mean VIF & & 1.16 & & & 1.24 & & & 1.30 & & & 1.34 & & & 1.49 & & & 1.64 & \\
\hline Country fixed effect & & No & & & No & & & No & & & No & & & No & & & No & \\
\hline
\end{tabular}

*Significance level 10\%;**significance level 5\%;*** significance level 1\%. 
Table 7. Robustness Checks (robust standard errors and Student t)

Section a: at announcement, 512 estimated regressions

\begin{tabular}{|c|c|c|c|c|c|c|c|c|c|c|}
\hline Core variables & Max & Min & Mean & Avg std & PercSign. 5\%level & PercSign.10\%level & Perc+ & Perc- & Avgt & Obs \\
\hline Efficiency & -0.0002 & -0.0003 & -0.0002 & 0.0001 & $71 \%$ & $100 \%$ & $0 \%$ & $100 \%$ & 2.0474 & 512 \\
\hline Roe & 0.0006 & 0.0004 & 0.0005 & 0.0002 & $68 \%$ & $87 \%$ & $100 \%$ & $0 \%$ & 2.1243 & 512 \\
\hline Friendly & 0.0207 & 0.0167 & 0.0185 & 0.0048 & $100 \%$ & $100 \%$ & $100 \%$ & $0 \%$ & 3.8631 & 512 \\
\hline National & 0.0151 & 0.0120 & 0.0135 & 0.0054 & $100 \%$ & $100 \%$ & $100 \%$ & $0 \%$ & 2.5001 & 512 \\
\hline Equity & 11.7746 & 9.9647 & 10.8506 & 4.1495 & $100 \%$ & $100 \%$ & $100 \%$ & $0 \%$ & 2.6286 & 512 \\
\hline Testing variables & Max & Min & Mean & Avg std & PercSign. 5\%level & PercSign. 10\%level & Perc+ & Perc- & Avgt & Obs \\
\hline Assets & 0.0017 & -0.0001 & 0.0009 & 0.0016 & $0 \%$ & $0 \%$ & $96 \%$ & $4 \%$ & 0.5435 & 256 \\
\hline Public & 0.0108 & 0.0043 & 0.0074 & 0.0057 & $25 \%$ & $50 \%$ & $100 \%$ & $0 \%$ & 1.3840 & 256 \\
\hline Concentration & 0.0101 & -0.0003 & 0.0051 & 0.0138 & $0 \%$ & $0 \%$ & $98 \%$ & $2 \%$ & 0.3625 & 256 \\
\hline Official & 0.0002 & -0.0009 & -0.0004 & 0.0012 & $0 \%$ & $0 \%$ & $5 \%$ & $95 \%$ & 0.3312 & 256 \\
\hline Capital & -0.0005 & -0.0015 & -0.0010 & 0.0012 & $0 \%$ & $0 \%$ & $0 \%$ & $100 \%$ & 0.8058 & 256 \\
\hline Transparency & 0.0042 & 0.0013 & 0.0028 & 0.0021 & $25 \%$ & $42 \%$ & $100 \%$ & $0 \%$ & 1.4310 & 256 \\
\hline Analysts & 0.0006 & -0.0063 & -0.0031 & 0.0054 & $0 \%$ & $0 \%$ & $3 \%$ & $97 \%$ & 0.5527 & 256 \\
\hline Big deals & -0.0039 & -0.0120 & -0.0089 & 0.0067 & $0 \%$ & $2 \%$ & $0 \%$ & $100 \%$ & 1.3079 & 256 \\
\hline
\end{tabular}

Section b: at completion, 512 estimated regressions $C A R[0,+1]$

\begin{tabular}{|c|c|c|c|c|c|c|c|c|c|c|}
\hline Core variables & Max & Min & Mean & Avg std & PercSign. 5\%level & PercSign. 10\%level & Perc+ & Perc- & $\operatorname{Avg~t}$ & Obs \\
\hline Abn returns_ac & -0.5176 & -0.8216 & -0.6661 & 0.2610 & $99 \%$ & $100 \%$ & $0 \%$ & $100 \%$ & 2.5596 & 512 \\
\hline Analysts & 0.0061 & 0.0039 & 0.0050 & 0.0030 & $0 \%$ & $62 \%$ & $100 \%$ & $0 \%$ & 1.6656 & 512 \\
\hline Official & 0.0021 & 0.0012 & 0.0017 & 0.0011 & $0 \%$ & $26 \%$ & $100 \%$ & $0 \%$ & 1.5273 & 512 \\
\hline Transparency & -0.0034 & -0.0043 & -0.0039 & 0.0017 & $100 \%$ & $100 \%$ & $0 \%$ & $100 \%$ & 2.2665 & 512 \\
\hline Big deals & 0.0142 & 0.0106 & 0.0124 & 0.0048 & $100 \%$ & $100 \%$ & $100 \%$ & $0 \%$ & 2.6152 & 512 \\
\hline Delta regulatory quality & 0.0064 & 0.0045 & 0.0054 & 0.0026 & $100 \%$ & $100 \%$ & $100 \%$ & $0 \%$ & 2.1205 & 512 \\
\hline Testing variables & $\operatorname{Max}$ & Min & Mean & Avg std & PercSign. 5\%level & PercSign. 10\%level & Perc+ & Perc- & Avg t & Obs \\
\hline Terminated & 0.0067 & 0.0029 & 0.0052 & 0.0046 & $0 \%$ & $0 \%$ & $100 \%$ & $0 \%$ & 1.1315 & 256 \\
\hline Dummy 0309 & 0.0071 & -0.0007 & 0.0028 & 0.0048 & $0 \%$ & $0 \%$ & $95 \%$ & $5 \%$ & 0.5484 & 256 \\
\hline National & 0.0040 & 0.0020 & 0.0030 & 0.0043 & $0 \%$ & $0 \%$ & $100 \%$ & $0 \%$ & 0.7069 & 256 \\
\hline Efficiency & 0.0001 & 0.0000 & 0.0000 & 0.0001 & $0 \%$ & $0 \%$ & $100 \%$ & $0 \%$ & 0.3447 & 256 \\
\hline $\mathrm{Pb}$ & 0.0053 & 0.0021 & 0.0035 & 0.0032 & $0 \%$ & $0 \%$ & $100 \%$ & $0 \%$ & 1.1028 & 256 \\
\hline Cash & 0.0009 & -0.0020 & -0.0006 & 0.0038 & $0 \%$ & $0 \%$ & $23 \%$ & $77 \%$ & 0.2024 & 256 \\
\hline Friendly & 0.0044 & 0.0027 & 0.0036 & 0.0036 & $0 \%$ & $0 \%$ & $100 \%$ & $0 \%$ & 1.0033 & 256 \\
\hline Delta volatility & -0.0018 & -0.0033 & -0.0024 & 0.0029 & $0 \%$ & $0 \%$ & $0 \%$ & $100 \%$ & 0.8434 & 256 \\
\hline
\end{tabular}


Section $\boldsymbol{c}:$ at completion 512 estimated regressions $C A R[0,+10]$

\begin{tabular}{|c|c|c|c|c|c|c|c|c|c|c|}
\hline Core variables & Max & Min & Mean & Avg std & PercSign. 5\%level & PercSign. $10 \%$ level & Perc+ & Perc- & Avg t & Obs \\
\hline Delta volatility & 0.0231 & 0.0164 & 0.0196 & 0.0081 & $100 \%$ & $100 \%$ & $100 \%$ & $0 \%$ & 2.4346 & 512 \\
\hline Minors nocoverage & 0.0252 & 0.0132 & 0.0196 & 0.0108 & $29 \%$ & $69 \%$ & $100 \%$ & $0 \%$ & 1.8079 & 512 \\
\hline Cash & -0.0121 & -0.0214 & -0.0170 & 0.0092 & $29 \%$ & $84 \%$ & $0 \%$ & $100 \%$ & 1.8444 & 512 \\
\hline Terminated & -0.0073 & -0.0298 & -0.0180 & 0.0095 & $45 \%$ & $72 \%$ & $0 \%$ & $100 \%$ & 1.8846 & 512 \\
\hline Dummy 0309 & -0.0116 & -0.0274 & -0.0182 & 0.0091 & $46 \%$ & $80 \%$ & $0 \%$ & $100 \%$ & 2.0022 & 512 \\
\hline Testing variables & Max & Min & Mean & Avg std & PercSign. 5\%level & PercSign. 10\%level & Perct & Perc- & Avg t & Obs \\
\hline National & -0.0005 & -0.0122 & -0.0066 & 0.0087 & $0 \%$ & $0 \%$ & $0 \%$ & $100 \%$ & 0.7637 & 256 \\
\hline Debt & 0.0193 & 0.0010 & 0.0122 & 0.0116 & $0 \%$ & $1 \%$ & $100 \%$ & $0 \%$ & 1.0590 & 256 \\
\hline Transparency & -0.0006 & -0.0055 & -0.0036 & 0.0032 & $0 \%$ & $1 \%$ & $0 \%$ & $100 \%$ & 1.1365 & 256 \\
\hline Equity & 19.9189 & 7.7084 & 14.5796 & 7.4500 & $49 \%$ & $68 \%$ & $100 \%$ & $0 \%$ & 1.9549 & 256 \\
\hline Friendly & 0.0000 & -0.0080 & -0.0048 & 0.0083 & $0 \%$ & $0 \%$ & $0 \%$ & $100 \%$ & 0.5809 & 256 \\
\hline $\mathrm{Pb}$ & 0.0021 & -0.0083 & -0.0034 & 0.0064 & $0 \%$ & $0 \%$ & $17 \%$ & $83 \%$ & 0.5770 & 256 \\
\hline Assets & 0.0048 & -0.0014 & 0.0019 & 0.0026 & $4 \%$ & $10 \%$ & $90 \%$ & $10 \%$ & 0.8414 & 256 \\
\hline Analysts & 0.0121 & 0.0011 & 0.0059 & 0.0080 & $0 \%$ & $3 \%$ & $100 \%$ & $0 \%$ & 0.7766 & 256 \\
\hline Big deals & 0.0189 & 0.0061 & 0.0115 & 0.0136 & $0 \%$ & $0 \%$ & $100 \%$ & $0 \%$ & 0.8392 & 256 \\
\hline
\end{tabular}


APPENDIX Description of Variables appearing in Tables 5 and $6 a$ and $6 \mathrm{~b}$

\begin{tabular}{|c|c|c|}
\hline Variable & Definition & Source \\
\hline Abn returns_ac & $\begin{array}{l}\text { Acquirer abnormal return between announcement and } \\
\text { completion date }\end{array}$ & $\begin{array}{l}\text { Our calculations on } \\
\text { Thomson Reuter data }\end{array}$ \\
\hline Concentration & $\begin{array}{l}\text { Asset of the three largest commercial bank to total mkt asset } \\
\text { in the acquirer country the year prior to the deal }\end{array}$ & $\begin{array}{l}\text { DICE CEisIFo-World } \\
\text { Bank }\end{array}$ \\
\hline Big deals & $\begin{array}{l}\text { Dummy variable whose value is } 1 \text { when the deal value is } \\
\text { greater or equal to } € 1 b n \text { and } 0 \text { otherwise }\end{array}$ & $\begin{array}{l}\text { Our calculations on } \\
\text { Bloomberg data }\end{array}$ \\
\hline Capital & $\begin{array}{l}\text { Index of regulatory oversight of bank capital, including } \\
\text { indicators for whether the sources of funds that count as } \\
\text { regulatory capital can include assets other than cash and } \\
\text { government securities, and whether authorities verify the } \\
\text { source of capital }\end{array}$ & World Bank \\
\hline Cash & $\begin{array}{c}\text { Dummy variable whose value is } 1 \text { when the deal is paid cash } \\
\text { or debt zero otherwise }\end{array}$ & Bloomberg \\
\hline Efficiency & $\begin{array}{c}\text { Efficiency ratio (ratio between expenditures and total } \\
\text { revenues) }\end{array}$ & Bloomberg \\
\hline $\begin{array}{l}\text { Delta regulatory } \\
\text { quality }\end{array}$ & $\begin{array}{l}\text { Differential between acquirer and target country regulatory } \\
\text { quality. Regulatory quality measures the ability of the } \\
\text { government to } \\
\text { formulate and implement sound policies and regulations. }\end{array}$ & $\begin{array}{l}\text { Our calculations on } \\
\text { World Governance } \\
\text { Indicators Data, } \\
\text { World Bank }\end{array}$ \\
\hline Analysts & $\begin{array}{l}\text { Dummy variable that takes value zero if - over the time } \\
\text { period in exam - the number of Bloomberg analysts } \\
\text { covering the acquirer bank is less or equal to two, one if the } \\
\text { number of analysts is more than two and less than ten, two if } \\
\text { there are more than ten analysts }\end{array}$ & Bloomberg \\
\hline Dummy 0309 & $\begin{array}{l}\text { Dummy variable taking value of } 1 \text { for deal completed after } \\
\text { march } 2009\end{array}$ & \\
\hline Public & $\begin{array}{l}\text { Dummy variable taking the value of } 1 \text { when the target is } \\
\text { public }\end{array}$ & $\begin{array}{l}\text { Our calculations on } \\
\text { Bloomberg data }\end{array}$ \\
\hline Friendly & $\begin{array}{l}\text { Dummy variable taking the value of } 1 \text { when the deal is } \\
\text { announced to be on friendly basis vs the target's managers }\end{array}$ & Bloomberg \\
\hline Delta volatility & Acquirer return idiosyncratic volatility ratio vol2/vol 1 & $\begin{array}{l}\text { Our calculations on } \\
\text { Thomson Reuter data }\end{array}$ \\
\hline Assets & Log of total asset on the year prior the year of the deal & Bankscope \\
\hline Equity & $\begin{array}{l}\text { Tangible equity to asset ratio orthogonalized with respect to } \\
\text { size(Assets) }\end{array}$ & $\begin{array}{l}\text { Our calculations on } \\
\text { Bankscope data }\end{array}$ \\
\hline Minors nocoverage & $\begin{array}{l}\text { Dummy variable that takes value } 1 \text { when deal value is less } \\
\text { than } € 250 \mathrm{mn} \text { and there are less than } 3 \text { analysts covering the } \\
\text { acquirer's activity. }\end{array}$ & $\begin{array}{l}\text { Our calculations on } \\
\text { Bloomberg data }\end{array}$ \\
\hline National & $\begin{array}{l}\text { Dummy variable taking the value of } 1 \text { when acquire and } \\
\text { target headquarter are located in the same country }\end{array}$ & Bloomberg \\
\hline Official & $\begin{array}{l}\text { Index of the power of the commercial bank supervisory } \\
\text { agency, including the rights of the supervisor to meet with } \\
\text { and demand information from auditors, to force a bank to } \\
\text { change the internal organizational structure, to supersede the } \\
\text { rights of shareholders, and to intervene in a bank }\end{array}$ & World bank \\
\hline $\mathrm{Pb}$ & Price to book ratio on the year prior the year of the deal & Bankscope \\
\hline Roe & Return on equity on the year prior the year of the deal & Bankscope \\
\hline Terminated & $\begin{array}{c}\text { Dummy variable taking the value of } 1 \text { when deal is } \\
\text { terminated }\end{array}$ & Bloomberg \\
\hline Transparency & Dummy representing the degree of transparency of the & Our calculations on \\
\hline
\end{tabular}




\begin{tabular}{|c|c|c|}
\hline & $\begin{array}{l}\text { target. It takes values } 0 \text { to } 4 \text { in relation to the availability of } \\
\text { economic information }\end{array}$ & $\begin{array}{l}\text { Bloomberg and } \\
\text { Bankscope data }\end{array}$ \\
\hline Volatility & $\begin{array}{l}\text { Return idiosyncratic volatility from } 250 \text { days to } 5 \text { days prior } \\
\text { the announcement }\end{array}$ & $\begin{array}{l}\text { Our calculations on } \\
\text { Thomson Reuter data }\end{array}$ \\
\hline \multicolumn{3}{|c|}{ Other variables } \\
\hline Anti director rights & $\begin{array}{l}\text { Revised anti-director rights index covers the following areas: } \\
\text { (1) vote by mail; (2) obstacles to the actual exercise of the } \\
\text { right to vote (i.e., the requirement that shares be deposited } \\
\text { before the shareholders' meeting); (3) minority } \\
\text { representation on the board of directors through cumulative } \\
\text { voting or proportional representation; (4) an oppressed } \\
\text { minority mechanism to seek redress in case of expropriation; } \\
\text { (5) preemptive rights to subscribe to new securities issued by } \\
\text { the company; and (6) the right to call a special shareholder } \\
\text { meeting. }\end{array}$ & Djankov et al. (2008)* \\
\hline Anti self-dealing & $\begin{array}{c}\text { Numerical measure of legal protection of minority } \\
\text { shareholders against self-dealing by corporate insiders. } \\
\text { Average of ex-ante and ex-post private control of self- } \\
\text { dealing. Measures the intensity of regulation of self-dealing } \\
\text { along a variety of dimensions, covering both public and } \\
\text { private enforcement mechanisms, such as disclosure, } \\
\text { approval, and litigation }\end{array}$ & $\begin{array}{l}\text { Djankov et al. } \\
(2008)^{*} \text {. }\end{array}$ \\
\hline Debteq & Debt to equity ratio on the year prior the year of the deal & Bankscope \\
\hline Debt & $\begin{array}{l}\text { Dummy that takes value } 1 \text { when the change in the } \\
\text { government debt to GDP ratio between } 2006 \text { and } 2009 \text { is } \\
\text { above } 15 \%\end{array}$ & $\begin{array}{l}\text { Our computations on } \\
\text { IMF WEO Data }\end{array}$ \\
\hline Fragility & $\begin{array}{l}\text { Ratio between the sum of deposits from other banks other } \\
\text { deposits and short term borrowing over total deposits plus } \\
\text { money market and short term funding on the year prior the } \\
\text { year of the deal }\end{array}$ & Bankscope \\
\hline Gover & $\begin{array}{l}\text { Arithmetic average of the following indicators: control of } \\
\text { corruption, government effectiveness, political stability, } \\
\text { regulatory quality, rule of law and voice an accountability }\end{array}$ & $\begin{array}{c}\text { World Bank/ World } \\
\text { Governance Indicators } \\
2010 \\
\end{array}$ \\
\hline Legal origin & $\begin{array}{c}\text { Dummy variable that takes value } 1 \text { when the country has } \\
\text { civil law as legal origin }\end{array}$ & Djankov et al. (2008)* \\
\hline Leverage & $\begin{array}{l}\text { Short plus long term funding on total asset on the year prior } \\
\text { the year of the deal }\end{array}$ & Bankscope \\
\hline Lmktcap & Log mkt capitalization on the year prior the year of the deal & Bankscope \\
\hline Vol1_idio & $\begin{array}{c}\text { Return idiosyncratic volatility from } 35 \text { to } 5 \text { days prior the } \\
\text { announcement }\end{array}$ & $\begin{array}{l}\text { Our calculations on } \\
\text { Thomson Reuter data }\end{array}$ \\
\hline Vol2_idio & $\begin{array}{l}\text { Return idiosyncratic volatility from } 1 \text { day after the } \\
\text { announcement to } 1 \text { day prior the completion }\end{array}$ & $\begin{array}{l}\text { Our calculations on } \\
\text { Thomson Reuter data }\end{array}$ \\
\hline Subgroup & $\begin{array}{c}\text { Dummy variable taking the value of } 1 \text { when acquirer and } \\
\text { target belong to the same business sub-group }\end{array}$ & Bloomberg \\
\hline Teq & $\begin{array}{l}\text { Tangible common equity to tangible asset on the year prior } \\
\text { the year of the deal }\end{array}$ & Bankscope \\
\hline & Subscript & \\
\hline $\mathrm{Ta}$ & Variable referring to the target & \\
\hline
\end{tabular}

* Djankov, Simeon, Rafael La Porta, Florencio Lopez-de-Silanes and Andrei Shleifer, 2008, The Law and Economics of Self-Dealing, Journal of Financial Economics 88, 430-465. 